Page 725-741. ISBN: 978-602-6 988-75-1

Web Jurnal Online: jurnal.unmuhjember.ac.id

By: Taufiq Hidayat

Money Politics In Pamekasan Regency

\title{
MONEY POLITICS IN PAMEKASAN REGENCY
}

\author{
By: Taufiq Hidayat \\ Fakultas Ilmu Adiministrasi Universitas Madura di Pamekasan. \\ Email: tauhidsosial@gmail.com
}

\begin{abstract}
Democracy in the context of state life is the best political and government system. Almost all modern countries accept the absolute need for democracy to be upheld. The implementation of the democratic system in Indonesia is not fully implemented according to the Pancasila and the 1945 Constitution. One of them is the General Election (Election) which is still full of the practice of money politics. The fundamental essence of each action of money politics can be seen from the mechanistic process or procedure and juridical. According to deliberative democracy it is implied in what is said to be practical discourse, the formation of political opinions and aspirations (politische meinung-und willenbildung), proceduralism or popular sovereignty as a procedure (volksouveranitat als verfahren). Deliberative theory in a model is interested in the issue of validity of collective decisions, namely the procedure for producing rules. Deliberative theory in a model is interested in the issue of validity of collective decisions, namely the procedure for producing rules. The practices of money politics played or played in each of the elections, are indicated by the development of a discursive, spatial model of money politics in opinions - between money politics and general elections which can be regarded as' the results of public use of communicative rights ".
\end{abstract}

Keywords: Mechanistic process, juridical, political aspirations 
Proceeding ICOGISS 2019

Page 725-741. ISBN: 978-602-6 988-75-1

Web Jurnal Online: jurnal.unmuhjember.ac.id

By: Taufiq Hidayat

Money Politics In Pamekasan Regency

\section{INTRODUCTION}

If you look at Indonesia in demonstrations carried out by students or educated community groups today at every election (elections), they tend to be anarchist in the name of the interests of the people or the nation. This is one of the reaction models of the repressive style of the previous regime, as a continuation of Dutch and Japanese occupation. In other words, after Indonesia's independence, in the era of the Old Order and in the era of the New Order, acts of violence often arose when there were differences between people. Such differences exist in the life of the community as evidence of the functioning of a democratic system. The 1945 Constitution mandates that the state in carrying out its functions deliver national goals based on a democratic system. The definition of democracy in general is freedom and equality. According to Sargen, that democracy implies the involvement of the people in decision making, the existence of equal rights among citizens, the existence of freedom and independence given to - or maintained by - and or owned by citizens, the existence of an effective system of representation, and the existence of respected elections principle of majority provisions. (In Fatah, 1994).

Voters in Indonesia still see the state of the country positively, but their attitude is not as optimistic as in 1999 when seven out of ten people felt that Indonesia was going in the right direction. Now, some voters (44\%) still believe that Indonesia is going in the right direction but a third of respondents feel pessimistic and 18\% feel unsure. The group that is bitter in its attitude is generally those who are younger, educated, and economically more capable, and those who are less fortunate are more positive in their attitudes. Meanwhile, the proportion of voters who said that the government did not care about their minds almost doubled compared to 1999 and 2003. In 2003, around 47\% felt that the government did not care about their minds, and 39\% said otherwise. This feeling of neglect arises especially among those who educate or those who are young - and once again, these numbers are not much different from the situation in other democratic countries. (In Team Meisburger's Results, Democracy in Indonesia; A Survey of Indonesian Voters 2003).

Therefore, to better understand political behavior including voter behavior in elections, a deeper understanding is needed of the extent to which a person's level of understanding and orientation has to his political world. One's orientation and understanding of the political world is what Almond and Verba call political culture. This orientation and understanding of the political world will guide a person in determining attitudes, opinions and more broadly determining his political behavior. (In Krisno Hadi et al., 2006). That is, understanding in understanding the political forces and behavior of political actors is based on the fact that every political actor and political force will always maximize their interests by using the opportunities and strength they have. While seeing the weaknesses of other actors in playing a role in their political interests can form patterns of interaction, norms, ethics, and culture that develop in the local community.

All of them, make openness and active participation in the interests of electoral which leads to the process of articulation of the achievement of power using all kinds of ways. One example is the practice of money politics that occurs in several electoral arrangements. For example, regional head elections by the DPRD, money politics also 
Proceeding ICOGISS 2019

Page 725-741. ISBN: 978-602-6 988-75-1

Web Jurnal Online: jurnal.unmuhjember.ac.id

By: Taufiq Hidayat

Money Politics In Pamekasan Regency

surfaced. Likewise in the direct regional head elections (Pilkada), for example, 147 residents of Bantarpanjang Village, Warudoyong Subdistrict, Sukabumi City, received an envelope containing Rp.10,000 with a message to elect one of the election participants (In Kompas, 10 April 2008)

In addition, Syamsuddin Haris said that political parties in carrying out candidates in regional head elections (pilkada) are more concerned with considering the financial capabilities of the candidates concerned, who are deemed to need a "boat" of political parties (In www. Komunitasdemokrasi.or.id/article/pilkada. pdf, downloaded on June 16, 2015). It was stated that prices were pegged by political parties between Rp. 1 billion and 2 billion for one candidate regent who was registered with the KPUD (Kompas, April 19, 2005). In the election of the Governor of Riau, a candidate must provide at least Rp. 400 million in "cash money" per seat to get a "boat". In this case the more strategic the position of the political party, the greater the amount of the application (Kompas, 6 July 2011). That is, against the weaknesses and strengths of the electoral system, each party has an internal policy to consider the options to be taken. Because, the choice of a particular electoral system will determine the fate and death of the party in the next election. Meanwhile, the form of formal participation places more emphasis on aspects of the process of public involvement in the discussion and provision of input. From that view, the problem arises, how is money politics in the lives of voters in the implementation of elections in Pamekasan Regency? The goal to be achieved is to identify and analyze money politics in the lives of voters in the implementation of elections in Pamekasan Regency.

\section{Study of Theory of Money Politics in the Democratic Perspective}

The maturity and capacity of the voter community as the nation's leaders and candidates to be elected is questioned by many groups. The questioning circles are related to the action of money politics, because the action of money politics is mostly carried out by educated groups of people that have a broad enough impact, especially on stability, security, order and public comfort. The politics of money can disrupt community activities, and of course it can also disrupt the local wisdom of culture. In short, where there is money politics, there is an act of suppression or violence. This will have an impact on the act of conveying aspirations and uses in their political interests. That is, the aspirations and utilization of political or public interests influenced by local culture and the role or form of state power will produce the desired and undesirable effects on public participation. The impact of public participation that is influenced by the desired local culture is only pematabaan and ethical values or morality of the community. The unwanted impact of public participation from the influence of local culture is any forms of intimidation and violence whatever the excuse.

Violence according to Galtung in Budi Santoso (2002: 169) is divided into personal and structural violence. The nature of personal violence is dynamic, easy to observe, shows great fluctuations that can cause change. Whereas structural violence is static, showing certain stability and invisibility. Structural violence is violence originating from structures that can be present in various forms such as the state. This violence is 
Proceeding ICOGISS 2019

Page 725-741. ISBN: 978-602-6 988-75-1

Web Jurnal Online: jurnal.unmuhjember.ac.id

By: Taufiq Hidayat

Money Politics In Pamekasan Regency

violence that is designed so that the way it works is very neat. The term violence itself is used to describe behavior, both open and closed or that is attacking or defensive.

From that view, making deliberations in developing important democratization contexts is realized in the public interest. The term "deliberation" comes from the Latin word deliberation, and in English becomes deliberation. This term means "consultation" weighs "or we have this political vocabulary" deliberation ". All these lexical meanings must be placed in the context of "public" or "political togetherness" to give full understanding as a concept in discourse theory. The merger with the term "democracy" gives special meaning to the concept of democracy. The concept in discourse theory, the term "deliberative democracy" has been implicit in what we have discussed above as practical discourse, formation of political opinions and aspirations (politische meinungund willenbildung), proceduralism or popular sovereignty as a procedure (volksouveranitat als verfahren). The theory of deliberative democracy does not focus on compiling a list of certain rules that show what must be done by citizens but on procedures to produce those rules. This theory raises the question, how political decisions are taken and in what conditions are these rules produced in such a way that citizens obey those rules. In other words, the model of deliberative democracy is interested in the issue of the validity of collective decisions. This model can adequately explain the meaning of democratic control through public opinion. Public opinions may be the opinions of the majority who claim their legitimacy. These opinions can also have a logical and coherent form that is considered valid universally and rationally. However, the majority opinions are not necessarily identical with the right opinions. For the model of deliberative democracy it is far more important to ensure that in what way the majority opinions are formed so that all citizens can obey those opinions. (In F. Budi Hardiman, 2013).

The rationality of the results of this political deliberation, as stated by Harbermas, is based on "the normative meaning of democratic procedures that should guarantee that all issues relevant to society are made the theme". In deliberative democracy all types of practical discourse operate in the formation of democratic opinions and aspirations to publicly examine the reasons for the proposed political rules. Determining legitimacy through discursiveness is the core idea of deliberative democracy.

In today's political theory there are other writers who emphasize the importance of rational deliberation processes, such as N. Bobbio, Dahl and J. Cohen. Where is the difference between the deliberative models Habermas and the other models design? There are three differences that need to be explained here to sharpen Habermas' thinking about deliberative politics. First, like other writers, Habermas also emphasizes democratic rules of play, guarantees the rights of freedom, the existence of competing parties, fair elections, majority principles, public debates and so on. (In F. Budi Hardiman, 2013).

Habermas tries to develop a model of context-sensitive democracy, a model that takes account of changes that have taken place in today's globalized complex societies. But the deliberative democracy intended by Habermas is not an analysis of the complexity of today's societies to prove that democracy is possible thanks to new developments in the field of information technology, such as the internet, multimedia, telecommunications and so on. Habermas actually attempts to show that democratization cannot be embedded from the outside into complex societies. Democracy develops from 
Proceeding ICOGISS 2019

Page 725-741. ISBN: 978-602-6 988-75-1

Web Jurnal Online: jurnal.unmuhjember.ac.id

By: Taufiq Hidayat

Money Politics In Pamekasan Regency

within the society itself and is driven by the political system that is already there. He believes that the communicative ratios that drive democratic processes are already available in the practices of the legal state and the institutions of the existing public space. Finally, the Habermas model also operates with ideal deliberation characteristics, such as the importance of the form of argumentation, the inclusiveness of the participants, freedom from the implementer, achieving consensus and so on. However, unlike the other models, Habermas focuses on the implementation of democratic procedures not only on a formally organized political system. If democracy means the government by the governed (die Regierung der Regierten), the implementers of this procedure must be stretched to form an unorganized and informal opinion formation in citizen communities, because "a praxis of deliberative self-determination can develop only in interactions between formations legal-procedural institutionalized aspirations programmed through policies and formation of political opinion in informal cycles of political communication. "Therefore, the Habermas model emphasizes what is called the" double track political deliberation process "in which there is a division of labor between the political system and public area. This model, the people no longer have space between one general election and another. The excessive role of the state operating according to the rationality of purpose (Zweckrationalitat) in front of citizens who communicate with everyday language is the real essence of the colonialization thesis that Habermas has analyzed in his book Theorie des kommunikativen Handelns. In the model of deliberative democracy many things are concentrated on the demands of democratization of 'space - between the two general elections. Of course the meaning of general elections should not be minimized, because general elections are the locus of citizens determining themselves. But elections are not the only locus. If democracy wants to be understood deliberatively, elections can be considered as 'the results of public use of communicative rights' (offentlicher Gebrauch der kommunikativen freibiten) which continues. According to Habermas the communicative rights of citizens are carried out mainly in informal discourses that can be carried out in an inclusive manner and can question all possible relevant themes. (In F. Budi Hardiman, 2013).

Therefore, for the sake of this research, the possibility of influences that can encourage, strengthen or give a tendency to examine group behavior and individual recipient societies and use the benefits of money politics, the researchers attempt to follow Spradley's advice (in Bungin, 2001) by finding relationships semantic (semantic relation ship) that is universal in analyzing domains as follows: Type, (strict inclusion); space (spatial); cause-effect; rational (rationale); locationale; means-end; function (function); sequence (sequence); attribute (atribution). In relation to how researchers use domain analysis techniques, the researcher carries out six steps from Spadley, namely: selecting certain semantic relationship patterns on the basis of information or facts available in researchers' diaries in the field; prepare a domain analysis work sheet; choose the similarities of data from researchers' diaries in the field; look for master concepts and symbolic categories of certain domains that correspond to a pattern of semantic relations; compile structural questions for each domain, and list all domains of all available data. In the findings reported here, researchers use words to describe the factors or themes that emerge. 
Proceeding ICOGISS 2019

Page 725-741. ISBN: 978-602-6 988-75-1

Web Jurnal Online: jurnal.unmuhjember.ac.id

By: Taufiq Hidayat

Money Politics In Pamekasan Regency

\section{Portrait of 2014 Voting Rights in Pamekasan Regency}

Of the total population in 13 sub-districts, not all have the rights and obligations as citizens to make choices in elections. But the voting rights in Pamekasan Regency are determined by the age of their voting rights. The right to vote in Pamekasan Regency can be described in the following table:

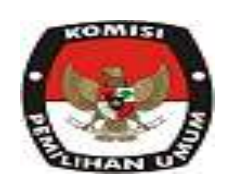

DISTRICT : PAMEKASAN

PROVINCE : EAST JAVA

RECAPITULATION OF REGENCY / CITY FIXED VOTERS

PRESIDENT GENERAL ELECTION AND REPRESENTATIVE OF

THE PRESIDENT OF 2014

BY DISTRICT / CITY KPU

\begin{tabular}{llcccccc} 
No & \multicolumn{1}{c}{ Name } & total & Total & \multicolumn{3}{c}{ Number of Voters } & Ket. \\
& \multicolumn{1}{c}{ District } & $\begin{array}{c}\text { Village/ } \\
\text { Kel }\end{array}$ & TPS & L & P & L + P & \\
& & & & & \\
1. & BATUMARMAR & 13 & 192 & 35.122 & 36.339 & 71.461 & \\
2. & GALIS & 10 & 49 & 10.658 & 11.689 & 22.347 & \\
3. & KADUR & 10 & 111 & 18.380 & 20.143 & 38.523 & \\
4. & LARANGAN & 14 & 79 & 20.252 & 22.704 & 42.956 \\
5. & PADEMAWU & 22 & 124 & 29.108 & 32.080 & 61.188 \\
6. & PAKONG & 12 & 84 & 13.741 & 14.591 & 28.332 \\
7. & PALENGA'AN & 12 & 151 & 37.869 & 37.264 & 75.133 \\
8. & PAMEKASAN & 18 & 157 & 31.760 & 34.805 & 66.565 \\
9. & PASEAN & 9 & 156 & 23.033 & 24.748 & 47.781 \\
10. & PEGANTENAN & 13 & 147 & 30.274 & 31.255 & 61.529 \\
11. & PROPPO & 27 & 135 & 31.140 & 33.397 & 64.537 \\
12. & TLANAKAN & 17 & 115 & 23.132 & 24.947 & 48.079 \\
13. & WARU & 12 & 145 & 25.839 & 26.458 & 52.297 & \\
& TOTAL & $\mathbf{1 8 9}$ & $\mathbf{1 . 6 4 5}$ & $\mathbf{3 3 0 . 3 0 8}$ & $\mathbf{3 5 0 . 4 2 0}$ & $\mathbf{6 8 0 . 7 2 8}$
\end{tabular}

Paying attention to the number of people entitled to vote above can be captured as a potential source in determining the role of participation in elections. This difference in the number of roles of population participation implies that population suffrage in a region can create a conducive atmosphere in various interests in the election, and can color productive activation in a variety of interests played by - from the actors at each election event held, so that it can shape voter behavior through its approach. The approach in this case David E Aptter states, lies in the relationship between political knowledge and political action, including how the process of forming political opinions, how political skills are obtained, and how people are aware of political events.

Such a thing can be captured that the community in the behavior and distribution of aspirations in the general election is slow. This means that it can be said by the community Pamekasan tendencies in their roles and political participation depend on the role of the actor who is close and understands the articulation of their cultural basic, so that they can form their opinions, interests and political rights needs in elections. 
Proceeding ICOGISS 2019

Page 725-741. ISBN: 978-602-6 988-75-1

Web Jurnal Online: jurnal.unmuhjember.ac.id

By: Taufiq Hidayat

Money Politics In Pamekasan Regency

\section{Description of public opinion in space - between money politics and general elections which can be considered as 'the results of public use of communicative rights'}

Opportunities for open money politics with a variety of methods occur at each election. This situation, will encourage individuals and groups of interest to use it as a space to maneuver to do political will through rewards, pressure or push the agendas of the movement in order to achieve goals in their power or position. Achieving goals through money politics does not only become a political opportunity at the local and national level, but also opens up political opportunities at the international level and encourages the emergence and expansion of the interest movement. Movement of interest through money politics will be effective if there are political opportunities that support it. Political opportunities in support can shape public opinion in the space between money politics and elections which are considered as the result of public use of the communicative rights that they have built. This is as said by Ach. Kusnindar (Dadank's everyday name), Ismail Chairperson of Commission I of Pamekasan Regency DPRD, Agus (candidate for DPRD from Golkar), Saiful Anam (Panwas of Pegantenan District), Suddur (PPS member), Ali Usman (PNS), Faqih (FIA Student) Madura University), Hakiki (Palengaan District PPS), Nurwidya Rahmi (FIA Student at Madura University).

"The election is indeed loaded with money politics, is common, entrenched, entrenched, and has made it as pragmatic. The opinion is a matter of agreement, the interests of the success team, stimuli to PPS, to individuals and to the Village Head, to community leaders (Tomas) or religious leaders (Toga), addressing community problems that are facing urgent problems to overcome, participation issues which otherwise there is money that will not vote, the problem of choice of the quality of the candidate, and the problem of grouping the number of candidates for those who have agreed to allocate money (for example, candidate A number and number B candidates) through instructions or appeals to the Chairperson of the PPS. In addition, the issue of the KPU which has castrated small Parties that are utilized in their interests, and the KPU also plays money politics by committing votes by throwing away, because there is a tendency for one of the candidates to be built by the candidate and voting rights.

The statement above if viewed from the meaning or meaning of the word is money politics is real and common in society, and also has become a culture or habit of candidates to use money to get the most votes. Politics of money is used as a pretext for travel, to eat a successful team, to meet the food needs of the community, and to increase participation. Second, in terms of linguistic forms (the science of language) is money politics is an embodiment of other forms of need. Third, its function as a symbol of money politics is to achieve sound success as expected. Fourth, the role played in relation to human words and actions from money politics is manipulative interests or influences the direction of voters. 
Proceeding ICOGISS 2019

Page 725-741. ISBN: 978-602-6 988-75-1

Web Jurnal Online: jurnal.unmuhjember.ac.id

By: Taufiq Hidayat

Money Politics In Pamekasan Regency

\section{The interests of society in space, between money politics and general elections which can be considered as "the results of public use of communicative rights"}

The opportunity of money politics interests that encourage the emergence of community movements in space, between money politics and general elections which can be considered as the result of public use of communicative rights can be further seen from government policies in facing the assertiveness of other forms of money politics opportunities not only through the model of rice assistance, money, but also the terror of voting letters from voters with compensation of money. This is as the core point of the results of interviews with Kusnindar, Suddur, Ali Usman, Ayu, Hakiki, Saiful Anam that, money political interests are rolled out as;

"The momentary interest for candidates to get a large number of votes, and for a moment for individuals as beneficiaries of money politics because if they were so they would not remember anymore and there would be no impact on the voter. In addition, to build politics in the cometment with candidates if later it has been made, for the needs of home or family, just having fun with friends, for the sake of the success team, so that there is connectivity that can be built with bureaucratic circles.

The statement if viewed from the meaning or meaning of the word is the politics of money in its interests only for a moment and makes the candidate as a meaningless society. The target is to fulfill household or family deadlock. In addition, making the opportunity for candidates to share with the community, and at the same time share the fun with their friends. The goal is to reap the votes of the voters desired, and individuals as beneficiaries are not in the quality responsibility. Whatever has been built in the network does not affect the unwanted, and the development of the network is structural cultural - its function. Second, in terms of linguistic forms (linguistic sciences), money political interests are just another form of compensation for vote acquisition. Developmental motives in luck to achieve the desired voice. Its consistency and connection is played in the role of actors electoral rational, pragmatic electoral and traditional electoral. Third, its function as a symbol of the interests of money politics is arrogance, acceptance in the inability to gain power or position. Fourth, the role played in relation to human words and actions from the interests of money politics is relative, accommodation and biased.

\section{Community needs - discourse in space, between money politics and general elections which can be considered as 'the results of public use of communicative rights'}

In winning contestation in elections through money politics in the region, the tendency to inspire all attitudes and demands of the actors. The attitude and demands of these actors are the affirmations, why civil society organizations whose actors are none other than campus activists, community leaders and religious leaders (Kiyai). Village leaders or village heads who have a vertically significant role dealing with community needs? The classic reason is that these actors are often discursive parties in fulfilling their interests through significant bargaining power to become their own strength in the voting movement of the candidates heading towards efforts to mobilize the masses in an organized manner. Organized mass in the role of actors vertically - horizontally, becomes 
Proceeding ICOGISS 2019

Page 725-741. ISBN: 978-602-6 988-75-1

Web Jurnal Online: jurnal.unmuhjember.ac.id

By: Taufiq Hidayat

Money Politics In Pamekasan Regency

a forum for the strength of the movement to design and mobilize as many people as possible on the needs of one candidate. In addition, it can convince the masses that money political movements are carried out, even though they have to use means of communication, pressure and can also be through legal or legitimate violence in quotes, both religiously and culturally (Madura). Bearing in mind, there is still an individual view of the needs of society in the space discourse, between money politics and general elections which can be considered as the result of public use of its communicative rights. This is as stated by Kusnindar / Dadank, Hakiki, Ali Usman, Suddur, that the discourse on the political needs of money has been rolled out:

"In order to achieve expectations be in power, just fulfill the needs of cigarettes and economic needs (food), as sodhakoh, and the community can compare the difference in money politics distributed by candidates based on needs, mass and the amount of money that is conditioned for society, so that many candidates are brave compete in offering the amount of money that is given by candidates for individuals, or for community groups, or for community leaders, or for religious leaders, or for village heads who are seen as profitable, for votes for candidates.

The statement if viewed from the meaning or meaning of the word is that money politics in needs discourse is for understanding the desired voter agreement with the candidate, so that the desired fulfillment of needs can be created, and marketable in the value of political interests. Second, in terms of linguistic forms (linguistics), the political interests of money in discursive needs are individuals at the target points of influence and can be influenced both individually and by groups of people in various ways to achieve the desired voice. Third, its function as a symbol of the political interests of money in discursive needs is structuralist, functionalist and systemic. Fourth, the role played in relation to human words and actions from the discursive needs of money politics is the amount of money value and programs for building worship places.

\section{Discussion}

The practices of money politics played or played in each of the elections, are indicated by the development of a discursive, spatial model of money politics in opinions - between money politics and general elections which can be regarded as' the results of public use of communicative rights ".

Therefore, in terms of the findings of research on money politics in each election implementation in Pamekasan Regency, it indicates that;

1. Community opinions in space, between money politics and general elections, prove that money politics in the electoral room is "real - real, clear and common in society". Having become habitual or entrenched, entrenched, as a problem solver for the economic needs of the community, can increase participation, can eliminate the significance of the quality of candidates, as a justification in its actions from candidates and the community. In addition, its use with various pretexts or models or behaviors, such as for traveling or eating a successful team, shodaqoh, musholla assistance, and is an embodiment of other forms of needs and immediate needs. Money politics exists, functions as a symbol of reaching the soundness of the sound as expected, menoton in making decisions. The role played in relation to his words and 
Proceeding ICOGISS 2019

Page 725-741. ISBN: 978-602-6 988-75-1

Web Jurnal Online: jurnal.unmuhjember.ac.id

By: Taufiq Hidayat

Money Politics In Pamekasan Regency

actions from money politics is manipulative, influencing the direction of the voter, transactional and buying votes, articulation of impasse, stagnation (stopping). This is the case, Habermas considers this type of public "wild" and "anarchic". People cannot organize or organize all public spaces ... The logical implication is that we can predict: public space is a locus for both manipulative communication and unlimited communication ... So according to Habermas, the formation of public opinion depends on certain formal criteria which turn is determined by the public itself. (In Budi Hardiman, 2013).

2. The interests of the community in space - between money politics and general elections. Judging from the results of interviews with informants, it shows that money politics in its interests only applies for a moment, making candidates as meaningless to the community, making agreements, perpetuating the interests of individual candidates with the community, making candidates as second interests after becoming in power, merely targets the need to fulfill a household or family deadlock, makes the opportunity for candidates to share with the community, while sharing the fun with their friends. In addition, money politics in its interests to reach / achieve the desired votes according to expectations, individuals as beneficiaries in accountability, make the team successful in sharing its network development both structurally - culturally its function, and anything that has been built in the network does not have an impact not wanted. The political interest of money is just another form of compensation for vote acquisition, and is a motive for development in achieving the desired voice, and is the consistency and connection played in the role of the actor to achieve the desired voice. Its function as a symbol of the interests of money politics is trust in its interactions, as well as acceptance in the inability to gain power or position. The role played in relation to human words and actions from the interests of money politics is relative, sporadic, arrogance, and accommodating. All of those interests are reflective and less concerned about common interests. Such thing, according to Habermas "people are more interacting based on self-interst and often ignore public interest so that people are in strategic relationships to achieve their own success. However, the risk of dissensus (conflict) is also getting higher, and the shared platform from the background knowledge of the German Lebenswelt-bhs (living world) is narrowing. Therefore Habermas states that the actors seek to reach a consensus about the rules that limit their strategic actions. These rules are legal norms. Law here serves as a bridge between communicative action and strategic action. Thus, on the one hand, a space remains open for strategic action, but on the other hand these strategic interactions must be bound by communicative actions. Law is a strategic operating and interaction space, but the same law is also the result of a consensus that can only be achieved, if the strategic actors leave their own success orientation and communicate with each other to achieve mutual understanding. (In Budi Hardiman, 2013).

3. Community needs in space discourse - between money politics and general elections. Looking at the results of the interview with the informant, it was illustrated that the practice of money politics in the needs of society in space discourse - between money politics and elections was massive and considered normal, not wrong, not taboo, 
Proceeding ICOGISS 2019

Page 725-741. ISBN: 978-602-6 988-75-1

Web Jurnal Online: jurnal.unmuhjember.ac.id

By: Taufiq Hidayat

Money Politics In Pamekasan Regency

structured, systematic and not sinful. Such a thing is certainly very dangerous in building the true articulation of democratization, and in developing a dignified legal civilization. Such a thing, can be an outbreak of internal medicine or power, because there is a tendency for manipulative and corrupt behavior in the process of formulating policy making or in the implementation of program policies produced when holding office or power. This can happen, considering when success in power or position through vote buying (money politics), and also the politics of money played is obtained from sponsors or promoters, the tendency towards collusion and nepotism will be built in the interests of the program. Discretionary money politics is still paternalistic and primordial, so that people have difficulty in making their choices independently, and society is politically politicized. Meanwhile, political parties are not functioning well in political education and the costs that must be provided are very large, as well as law enforcement has not been going well. Laws and regulations that apply, may not be unilaterally determined and applied by and / or only for the interests of the authorities in contravention of the principles of democracy. Therefore Habermas, in the starting point of the question is: how can legal norms be obeyed on the basis of respect for laws in such a way that the legal norms become effective for social coordination? Or are legal norms valid? (In Budi Hardiman, 2013). Taking into account Habermas's question and if it is related to the issue of money politics in elections, it implies that legal norms that are valid or product laws must be able to be upheld and can be implemented as the context of norm or legal understanding in the interests of social coordination. If it cannot be enforced, the practice of money politics remains an undisputed icon of public opinion. Where the massive practice of money politics in public opinion considers it normal and not wrong in its use (balance in its interests). This means that money politics in the interests of elections becomes something that will not be touched by the law. If money politics has become a stereotype that will not be touched by the law, of course in turn it becomes very dangerous in building the true articulation of democratization, and in building a dignified legal civilization. Considering the epidemic of the practice of money politics that is large enough to buy voters' voices is not balanced with the income earned when achieving success in office or power, then there is a tendency for manipulative and corrupt behavior in the process of formulating policies or in implementing program policies when taking position or power. This tendency is quite basic because of the interest or need to return the money that has been spent during the nomination. In addition, the money that was rolled out to the community at the election momentum, also came from investors or entrepreneurs, and or also came from sponsors or promoters. If money politics is used in elections from sponsors or promoters, then the tendency towards collusion and nepotism will be built in the interests of the program, so that such things will give birth to injustice or impartiality to the people who are far from luck socio-economically. Meanwhile, money politics spread to the public as if it were campaign costs and improper campaign costs were carried out by the candidates systematically, and structured. Therefore Habermas in his procedural theory of legitimacy says that, the law must be obeyed, the law must also be accepted intersubjectively by its targets. Then, the validity or legitimacy that comes from 
Proceeding ICOGISS 2019

Page 725-741. ISBN: 978-602-6 988-75-1

Web Jurnal Online: jurnal.unmuhjember.ac.id

By: Taufiq Hidayat

Money Politics In Pamekasan Regency

intersubjective acceptance gives it binding power. Laws that demand compliance with their targets must also guarantee the same freedoms for everyone. (In Budi Hardiman, 2013).

Thus, the weaknesses in direct elections include the fact that most societies are still paternalistic and primordial, so that people have difficulty making their own choices independently, and society is politically politicized. This is all happening, because the political parties are not functioning well in political education and the costs that must be provided in direct general elections are very large, in addition to the enforcement of the law has not been going well. Not yet the establishment of good law, it is necessary to adhere to and practice the principles of democracy or popular sovereignty which guarantee the participation of the community in the state decision-making process. State decisions on each statutory regulation that are established and enforced - as justice that lives in the midst of society. Laws and regulations that apply, may not be unilaterally determined and applied by and / or only for the interests of the authorities in contravention of the principles of democracy. Because the law is not intended to only guarantee the interests of fairness for all people without exception. Thus, the rule of law (rechsstaat) developed is not 'absolute rechtsstaat', but 'democratische rechtsstaat' or a state of law that is nomocratic must be guaranteed the existence of democracy, as in every democratic country must be guaranteed based on law. Such matters are important, because the main concepts and symbolic categories of an analysis domain of money politics in each election implementation in Pamekasan Regency can be tested according to the following semantic relations;

1. The domain of the type of money politics in the form of its relationship with electoralism is a kind of motivation for people to make their choices. The structural question of money politics is whether the whole type or form of political practice in society is a cultural pattern in Pamekasan?

2. The domain of prospective and recipient actors in relation to the space between money politics and electoral is a part of public space. The public is located in the space of actors or actors or institutions. The structural question from the actor or actor or institution is whether the actor or actor or institution is also the holder or role player?

3. Domain causes of the recipient / player's role in the relationship of money politics is a need as a result of feeling gain profit. The advantage is because someone receives and or plays the role of money politics. The structural question of money politics is what are the causes of the acceptance and or role of political money?

4. The rational domain or the reason for the voting community in Pamekasan Regency in relation to money politics is the low level of welfare and sharing of pleasure with friends is the reason a person can receive political money. The structural question of money politics is that what is the reason or rationalization they choose the target of voters at the level of welfare and the willingness to share their interests with their friends as a place to play their political role?

5. The domain of concentration of the recipient community and / or the role player for the location of activities in the relationship of money politics is Kampung or Dusun or Rukun Warga which are the polling area. The structural question of money politics is 
Page 725-741. ISBN: 978-602-6 988-75-1

Web Jurnal Online: jurnal.unmuhjember.ac.id

By: Taufiq Hidayat

Money Politics In Pamekasan Regency

where are the concentration places of the voters using their voting rights in the use of money politics?

6. Domain tips to overcome the need for success in gaining power or position in the relationship of money politics is work through a model or trick or pattern that is disguised to obtain sound support and not touched by law. The structural question of money politics is that there are all the ways or tricks or models or patterns used by political actors to overcome the need for votes that are expected to be.

7. The function domain of money politics in relation to electoral is money politics is used to inventory voting rights in the corridors of its interests. The structural question of the function of money politics is what can be used by actors (recipients or players) in the changing direction of the voter community?

8. The domain of the sequence or stage of money politics played in relation to electoral affairs is to build a comet or conspiracy or infidelity in money politics in the family stage. The structural question of the order or stages of the existence of money politics is what are the sequences or stages of the construction of a comet between candidates as givers and individuals or groups of people as recipients of daily activation? Or How were the stages of the cometmen or conspiracy or political money infidelity built or rolled out in Pamekasan Regency?

9. The domain of the characteristics of money politics played in its contribution related to electoral is an attribute of one's own wealth. The structural question of money politics is what are the overall characteristics of money politics in its contribution in Pamekasan?

From the domain of money politics analysis it reminds of a situation or mostly where election violation cases including money politics cannot be proven because it is carried out by parties or actors supporting candidate pairs who are not registered in KPUD and through tricks or methods or models or blurring patterns substance of evidence or legal material. Then, the campaign period was very short - causing insufficient time for political awareness and selling programs. This, which in turn encourages candidates or pairs to make short cuts, such as doing money politics. In general, money politics is defined as art to gain victory in the struggle for power. While political money is only as access to obtain the victory (Sumartini in Hastuti et al, 2012). Meanwhile, the limitation of the perpetrators of money politics is people who give political money to either candidates, supporters or success teams and recipients of political money in any form. Money politics is carried out consciously by those who practice money politics. (In Ismawan, 1999).

Judging from the view of the meaning above shows that the existence of money politics is a fun (as art), and political money is a form of social network developer (as access) in achieving success in support of victory in elections. The successful acquisition of victory support for candidates for power or position through money politics is a campaign tool, so that the aspects of the similarity of campaign space in money political media become limited because the political media in question cannot be fair to encourage the similarity of opportunities to interact in unanimous understanding. Therefore, the principles of regulating political funds are accurate in electoral matters, and the firmness of sanctions for money politics is in accordance with applicable laws. But this makes it 
Proceeding ICOGISS 2019

Page 725-741. ISBN: 978-602-6 988-75-1

Web Jurnal Online: jurnal.unmuhjember.ac.id

By: Taufiq Hidayat

Money Politics In Pamekasan Regency

difficult for law enforcement because those who practice money politics are shadow teams that are not registered in the Election Commission. The legal process in money politics that arrived at a final final decision was also difficult for law enforcement because it would take a long time to be fixed.

In the practice of money politics in the General Elections in Pamekasan Regency, it was found that the actions of successful actors or teams in money politics movements formed from interactions to in a process or event, so as to form a routine and occur in the space and time of activities, such as campaigns. gathering of successful teams, religious activities, hospitality, stalls as political arenas and marches (see interview results). These are all actions in social manifestations, which Giddens states that social practices are repetitive actions that occur in space and time (Giddens in Priyono, 2003).

\section{Conclusion}

From the explanation above, it can be concluded that the essence of democracy is the involvement of the people in political decision making, the level of equal rights among citizens, the level of freedom and independence given to or maintained and owned by citizens, a system of representation, electoral systems and majority provisions. In a democratic country people no longer question citizens having equal rights to participate in democratic processes. Countries that are based on democracy will get popular sovereignty through the electoral process. In implementing democracy, the phenomenon of direct elections did not fully go well. Based on the findings of the data through interviews with informants, it shows that power is obtained through elections with tricks or ways of money politics. Tricks or ways of money politics are used consciously, certain planners, systematic and with the pretexts of religious nomenclature (such as Sodhakoh). This, can affect the candidate's psychological and psychological beneficiaries in his memory, so that it can shape the ability of the prospective actor to be in power, as well as actors who benefit from money politics into pragmatic understanding. Likewise the ability to express something of his actions as justifiers in his model. In Giddens's view (2010) it says as the concept of awareness on psychological mechanisms in the form of actions and will be interpreted as discursive and practical awareness. Discursive awareness is more directed at the agent's ability to express something for the actions he does. Instead practical awareness is more on the practical knowledge of agents that are difficult to decipher. While the inability to express something on action is called unconsciousness.

The Constitution has a role as a regulator in the implementation of general elections both at the level of Regency / City, Provincial and Central Levels directly. Aside from being a juridical basis in carrying out its authority as a government policy in the Electoral process, the constitution is also a post-election juridical basis, so that the Regional Head / Deputy Regional Head, Governor / Deputy Governor and President / Vice-President who win the election must be truly high people's mandate in carrying out government policies. However, the laws and regulations that exist in Election can not be carried out purely and consequently, thus creating an order of electoral that is biased or chaotic, less accommodating in its implementation, weak in material or legal evidence from the money politics that is rolled out (read the interview results about difficult tools 
Proceeding ICOGISS 2019

Page 725-741. ISBN: 978-602-6 988-75-1

Web Jurnal Online: jurnal.unmuhjember.ac.id

By: Taufiq Hidayat

Money Politics In Pamekasan Regency

or evidence material), less integrated in the similarity of perceptions or views or understanding of actors organizing Election over the product of legislation to legally ensnare the practices of money politics that are properly heard - really seen - really known - truly felt - really done with excuse the candidate with his successful team through his model. Meanwhile, the law on enforcement in Election is indeed not intended to only guarantee the interests of fairness for all people without exception, but the certainty of its application is based on the context and the content of the problem.

On the other hand, political parties have not played their role in the learning process or the people's political education. This happens, because political parties are faced with huge costs that must be provided in the direct election of regional heads or provincial heads and heads of state of the President. This is why the role of political parties is not optimal in positioning themselves to the public to provide the process of learning or political education that should, because political parties are only busy / busy themselves with accommodative practices of money politics to be used as political vehicles for their candidates, and practice accommodating money politics to carry out movements to gain votes from candidates from their parties. Then coupled with Election organizers, namely the KPU also considered by the community to play with money politics (re-read the results of interviews with informants), so that this can create a bad precedent in the process of public education or the people's learning process, and will also be a bad precedent in socializing the interests of organizing Election.

All of that, can endanger the very large joints of democratization, in addition to law enforcement which also cannot be implemented properly. Laws and regulations that apply, may not be determined and applied unilaterally by and or only for the interests of the authorities in contravention of the principles of democracy.

\section{Recommendations}

Noting the conclusions of the study, it is important that recommendations be conveyed in the results of this study, in order to obtain an idea of what can be anticipated in the interests of holding a full-rooted election - which is entrenched with the practices of money politics in each election organizer.

First, it needs to be adhered to and practiced by the candidates and their success team in the election contestation to build a joint agreement not to carry out money practices under any pretext. This needs to be stated implicitly through print media and electronic media, as well as the memorandum of understanding and agreement made by candidates, successful teams and communities explicitly through what is called the MoU.

Second, the affirmation of wrong-wrong-sin gives anything with a motive or pretext at the time of the election in the process or in the implementation of the election. Then, enforce and or provide ethical actions and sanctions against what is clearly clearly heard-perceived-carried out by the successful candidate-team-administrators of the main tasks and functions of the election in the field. Obviously, in this case, there is an indication of the direction of support using money politics with the pretexts of tricks for candidates A or B, as well as ethical and sanctions that are evident in the beneficiaries of money politics under any pretext. All of these must be binding legal instruments for understanding and agreement on articulation of forms, models, tricks, methods or 
Page 725-741. ISBN: 978-602-6 988-75-1

Web Jurnal Online: jurnal.unmuhjember.ac.id

By: Taufiq Hidayat

Money Politics In Pamekasan Regency

methods on the circulation of money politics in practice. Furthermore, the legal sanctions can be enforced by all instruments and / or officers along with the equipment for organizing the General Election. Such a thing, the principle of democracy or popular sovereignty that guarantees the participation of the community in the state decisionmaking process is truly realized, so that every legislation stipulated and enforced as justice that lives in the community can be implemented or realized purely and consequently.

Third, the success of law enforcement is demanded by many things; the first law must be just, second, law enforcement officers must be good and have high morality, election administrators (in this case KPU) must be ethical and professional in carrying out their main duties and functions of legislation, thirdly, the public must have sensitivity and legal awareness in the sense of understanding and having a legal culture so that it has a pattern of compliance that is not only obedient but critical.

Fourth, Law as an instrument of each election implementation must be truly seen as a law and positioned according to its interests. The law is reviewed in terms of its contents, so the law can be understood, lived and practiced purely and consequently by all citizens in a region. Law is reviewed as a command of the ruler, so it is important to show and or manifest behavior as its designation. Laws are reviewed in terms of requirements, so sanctions, orders, obligations, and sovereignty must be properly enforced according to the substance content in the context and in the content. This is the case, according to the Law of Legal Positivism, the authority that forms the law is a sovereign ruler, whose form is identical to the law, and is applied to those who are controlled. 
Page 725-741. ISBN: 978-602-6 988-75-1

Web Jurnal Online: jurnal.unmuhjember.ac.id

By: Taufiq Hidayat

Money Politics In Pamekasan Regency

\section{BIBLIOGRAPHY}

Lucia Ratih Kusumadewi, 1999. Attitudes and Religious Tolerance among Students: Studies in Three Universities in Jakarta. Essay. Depok: FISIP UI.

"Suing Student Intellectualism" in http: // bermula.wordpress.com/ 2008/06/25 / suingintellectualism-students /.

Margaret, Poloma M., 2000. Contemporary Sociology, fourth print, September, Division of Books for Higher Education, PT RajaGrafindo Persada, Jakarta.

Budi F. Hardiman, 2013. Deliberative Democracy: Considering 'State of Law' and 'Public Room' in Jurgen Habermas's Discourse Theory, 5th Printing, Kanisius (IKAPI Member), Yogyakarta.

Douglas Ramage; Roderick Brazier; Robin Bush; Hana Satriyo; Zacky Husein; Kelly Deuster; Wandy N. Tuturoong; Sandra Hamid, Democracy in Indonesia; A 2003 Indonesian Voter Survey, Project Leader \& Editor: Tim Meisburger, The Asia Foundation.

Hadi, Krisnhno; Susilo, Joko; Anwar, M. Khoirul; Habib, Achmad, M; Said, Mas'ud; Salviana DS, Vina; Suroso, Agus; Sulistyowati, Tutik; Nurjaman, Asep; Yutanti, Widya; Hamidi; Machmud, Muslimin, 2006. Political Party Behavior, UMM Fisip Research Team and Editor: M. Khoirul Anwar, Vina Salviana DS, First Print, December.

Ismawan, Indra. (1999). Money politics (influence of money in elections). Yogyakarta: Media Pressindo.

Giddens, Anthony. (2010). Structural theory. Translated by Maufur and Daryatno.Yogyakarta: Pustaka Pelajar. 